\title{
CRANIOCEREBRAL INVOLVEMENT IN LYMPHOMA
}

\author{
JORGE D. CORREALE*-DAVID A. MONTEVERDE*-JOSE A. BUERI* \\ EDGARDO G. REICH*-NESTOR LUCATELLI**
}

\begin{abstract}
SUMMARY - Nine-hundred-eighty-nine patients with lymphoma were studied. Fifty-three cases (5.3\%) had lymphomatous craniocerebral infiltration. The principal factors of risk for this complication were: advanced stage of the lymphoma (III or IV), diffuse histiocytic, diffuse poorly differentiated lymphocytic, or mixed cellularity lymphoma histological type, bone marrow involvement, and previous systemic chemotherapy. Thirty-two per cent of the cases of meningeal lymphomatous infiltration were asymptomatic and represented autopy findings. CT-scan was an useful test to detect brain focal parenchymatous infiltration, as opposed to meningeal infiltration. Mean survival time in patients with lymphomatous meningeal infiltration was 4.3 months, following the combined use of systemic chemotherapy, radiation therapy and intrathecal methotrexate. Two cases had primary cerebral lymphoma, a)though without associated immunodeficiency Twenty patients (2\%) had intracranial hemorrhage, in clear relationship with platelt alterations. Fifteen patients (1.5\%) had CNS infection, caused by common bacteriae or ipportunistic agents. In 7 cases, the diagnosis was made at autopsy. Thirty-six autopsies here performed. In 8 cases (22\%), pathologic findings such as, demvelination, microcalcificat.ons, coagulative necrosis, or gliosis, suggested complications from treatment.
\end{abstract}

\section{Infiltración linfomatosa craneocerebral.}

RESUMEN - Fueron estudiados 989 Dacientes con linfoma. Tuvieron infiltración linfomatosa craneocerebral 53 casos $(5.3 \%)$. Los principales factores de riesgo para esta complicación fueron: a. estado avanzado del linfoma (III D IV); b. las formas difusas histiocíticas, difusa pobremente diferenciada o celularidad mixta; c. el compromiso de la medula osea y de la quimioterapia sistémica previa. En el $32 \%$ de los casos la infiltración meníngea linfomatosa fú́ asintomática y renresentó hallazgos de autopsia. La tomografía cerebral fué de utilidad para detectar infiltraciones parenquimatosas focales, no asi para las inflitraciones meningeas. El tiempo medio de sobrevida en pacientes con infiltración meníngea linfomatosa fué de 4.3 meses, siguientes al uso cumbinado de terapia radiante a craneo total, quimioterápia sistémica y/o intratecal con methotrexate. Dos casos con linfoma cerebral primario no estuvieron asociados con inmunodeficiencia. Hemorragias intracraniales se observaron en 20 paclentes (2\%), en relación con alteraciones plaquetarias. En 15 casos hubo infección del SNC (1.5\%), causada por hacterias comunes o por agentes oportunistas. En 7 de esos casos el diagnóstico se hizo por autopsia. En $\dot{x}$ de 36 casos alitopsiados (22\%) se observaron desmielinización, microcalcificaciones, necrosis coagulativa o gliosis, sugestivas de complicaciones por los tratamientos efectuados.

In recent years, advances in the treatment of lymphoma have permitted a longer life expectancy, and consequently the appearance of neurological complications in more advanced stages of the disease. Most of the drugs used in the treatment of lymphoma have difficulties penetrating the blood-brain barrier. For that reason, lymphomatous cells localized in the central nervous system (CNS) may not be reached by chemo-

From the Division of Neurology (*) and Division of Pathology (**), José Maria Ramos Mejia Hospital, Buenos Aires. 
therapeutic agents, and may proliferate at that level. Bone marrow involvement from lymphomatous invasion, medication toxicity, or both, can determine abnormalities in the number and function of platelets, with subsequent occurrence of hemorrhagic phenomena. The use of chemotherapeutic agents and radiation therapy (RT) has also brought about new complications. Chemotherapy or RT can have direct toxic effects on the CNS which, in turn, can produce necrotic lesions, demyelinating microangiopathy, or a subacute necrotizing leukoencephalopathy. Secondly, treatment can produce immunodepression superimposed to the immunological deficiency caused by the lymphoma, thus creating conditions for the development of opportunistic infections.

In the present study, we assess the different craniocerebral lesions caused by the above mentioned mechanisms in patients with lymphoma.

\section{SUBJECTS AND METHODS}

Four-hundred-twenty-four inpatients were studied prospectively between 1984 and 1987 in the Neurnlngy and Hematology Departments of the José María Ramos Mejía Hospital of Buenos Aires. They all had a diagnosis of lymphoma. In a small proportion of patients, initial neurological symptoms led to the subsequent diagnosis of lymphoma. At the same time, 565 outpatient charts were reviewed, all of them with diagnosis of lymphoma. This made a total of 989 cases. F'ive-hundred-sixty-three cases corresponded to non-Hodgkin's lymphoma (NHL), while the remaining 426 to the Hodgkin's type (HL). In our population, 73 patients $(7.4 \%)$ had evidence of craniocerebral involvement consisting of lymphomatous infiltrations, heunorrhages, infections or complications from treatment. The diagnosis of CNS lymphomatous infiltration was based on either: (a) the presence of signs and symptoms of craniocerebral involvement in patients with diagnosis of lymphoma, in whom there was evidence of structural abnormalities shown by ancillary methods such as CT scan of the head, brain radionucleide scan or plain X-Rays of the skull, and in whom there was improvement or disappearance of the pathological images and of the clinical sympioms after treatment with chemotherapy, RT, or both; or (b) cerebrospinal fluid (CSF) cytology, brain biopsy, or autopsy.

Analysis of the clinical picture included age of the patient, sex, duration of the disease, hiatological type of lymphoma, clinical stage, bone marrow involvement, CSF atudy, ancillary methods, treatment adninistered, and response. Treatment included RT at doses from 2400 to 5000 Rads over 15 to 20 sessions, systemic chemotherapy (SCh), intrathecal methotrexate administration (IT Mtx) followed by leucovorin rescue, or a combination of them. The only patients who underwent surgery were those who had neurological involvement as the initial clinical picture, i.e., a space-occupying mass, and in whom diagnosis of lymphoma was unknown yet. Hemorrhagic phenomena were demonstrated by means of C'T scan or autopsy, when the latter was performed. Diagnosis of CNS infection was based on Hooper's criteria for imniunosuppressed patients 26. Complications from treatment were included when verified by pathological studies in patients that received $R T$, SCh, or $1 T$ Mtx. A total of 36 autopsies were performed. NHLs were classified according to the histological criteria of Rappaport 5t. For the HLs, Luke's criteria were used 41. Clinical stage was established according to the recommendations of the Ann Arbor Conference 5. One case of Burkitt's lymphoma was also included.

\section{RESULTS}

INFILTRATIONS - Meningeal, brain, or skull lymphomatous infiltrations were seen in 53 patients $(5.3 \%)$. There were 39 cases with NHL, 12 with HL, 1 with Burkitt's lymphoma, and 1 with a T-cell type lymphoma. In the NHL group, there were 25 men and 14 women. Their mean age was $48 \pm 17.3$ years. Duration of the disease, from the time of diagnosis of lymphoma until the appearance of the first neurological symptom, was 26.4 months (range 1-108 months). In 5 patients $(13 \%)$, the neurological picture was the first manifestation of the disease. In the HL uroup, there were 7 men and 5 women. Their mean age was $37 \pm 16$ years. Duration of the illness, at the time of the neurological complication, was 52.9 months (range 1-84 months). The lynphoma histological types are summarized in Table 1. There was a clear relationship between the clinical stage of the lymphoma and the occurrence of CNS lymphomatous infiltration. Eleven per cent of the cases with lymphomatous infiltrations were on stages II $A$ or $B, 22.7 \%$ on stages III $A$ or $B$, and $66 \%$ on stages IV A or $B$.

Thirty-one patients had leptomeningeal lymphomatous infiltrations. In 19 cases, there were brain parenchymatous inflitrations. Ten patients had inflltration either circumscriłed 


\begin{tabular}{|c|c|c|c|}
\hline & Non-Hodgkin's Lymphoma & Hodgkin's & Lymphoma \\
\hline \multicolumn{2}{|r|}{ No of cases } & & No of cases \\
\hline D-PDLL & 15 & $\mathrm{MC}$ & 8 \\
\hline D-HL & 14 & LD & 3 \\
\hline D-ML & 9 & NS & 1 \\
\hline NHL & 1 & & \\
\hline
\end{tabular}

Table 1 - Histological classification of lymphoma in patients woith cramiocerebral infiltrations (one patient with Burkitt's lymphoma and another with $T$-cell lymphoma are not included in this table). D-PDLL, diffuse poorly differentiated lymphocytic lymphoma; $D-H L$, diffuse histiocytic lymphoma; D-ML, diffuse mixed lymphoma; $N H L$, nodular histiocytio lymphoma; $M C$, mixed cellularity; LD, lymphocyte depletion; NS, nodular sclerosing.

to the orbit or extending to adjacent areas. Finally, four patients had infiltration of the skull. In 11 cases, there was a combination of brain parenchymatous lymphomatous infiltration with either meningeal or orbital involvement. Ten cases of lymphomatous meningeal infiltration were diagnosed at autopsy, without any prior indication of such an involvement. Two cases corresponded to primary cerebral lymphomas (PCL) of the diffuse histiocytic type. Their age at onset was 57 and 52 years, and their survival time was 8 and 11 months, respectively. None of them had associated immunodeficiency. Eight patients with brain meningeal infiltration had concomittant spinal cord involvement. Forty-five patients with craniocerebral infiltration underwent a bone marrow biopsy, which showed lymphomatous infiltration in $70 \%$ of them. However, when considered separatedly, patients with HL and craniocerebral infiltration had bone marrow involvement in all cases. The commonest symptoms and signs are summarized in Table 2.

\begin{tabular}{|c|c|c|}
\hline Symptoms and signs & Nu of cases & Percentage \\
\hline Headache & 23 & 43.0 \\
\hline Visual disturbances & 17 & 32.0 \\
\hline Confusion & 13 & 24.5 \\
\hline Nausea-vomiting & 8 & 15.0 \\
\hline Paresthesiae & 4 & 7.5 \\
\hline Photophobia & 4 & 7.5 \\
\hline Psychiatric disturbances & 3 & 5.0 \\
\hline Gait disturbances & 3 & 5.0 \\
\hline Cranial nerve dysfunction & 23 & 43.0 \\
\hline Focal weakness & 13 & 24.5 \\
\hline Nystagmus & 10 & 18.0 \\
\hline Meningeal signs & 9 & 17.0 \\
\hline Seizures & 8 & 15.0 \\
\hline Cerebellar signs & 4 & 7.5 \\
\hline
\end{tabular}

Table 2 - Symptoms and signs in patients with craniocerebral lymphomatous infiltration.

CSF study revealed lymphoma cells in only 14 of 18 patients in whom a subsequent autopsy showed craniocerebral lymphomatous infiltration. In 21 patients with meningeal infiltration, the CSF study showed elevated protein and the presence of lymphomatous cells in $82 \%$ of the samples. Twenty-three per cent of the cases also had low glucose in CSF. 
In all cases with brain parenchymatous or skull lymphomatous infiltration, pasitive findings were seen on the CT scan. In $55 \%$ of the cases, there were single hyperdense images, which enhanced homogeneously after contrast administration. In the remaining cases, the images were isodense but enhanced after contrast administration. In all cases, they had varying degrees of surrounding edema and mass effect, depending on their size. They were contiguous to either the cortex or the ependymum. On these studies images either correlated with the pathological findings or disappeared after specific treatment. Nevertheless, CT scans of the head were negative in patients with lymphomatous meningitis except for one case, where there was periependimal contrast enhancement sugresting meningeal involvement.

Fourteen patients with CT scan images consistent with focal brain infiltration were treated with RT. There was subsequent disappearance of the lesions in 9 patients (64\%). Twenty-one cases of lymphomatous meningeal infiltration were treated with a combination of RT at doses of 2400 to 4000 Rads, SCh, and IT Mtx. None of them showed a satisfactory response to treatment. Their survival time had a mean of 4.3 months from the onset of symptoms.

HEMORRHAGES - Twenty patients (2\%) had intracranial hemorrhages. Among them, 18 had abnormalities in the platelet count or function. Two cases had an elevated platelet count, and they had intracranial hemorrhages secondary to platelet function abnormalities. The types of the intracranial hemorrhages were: diffuse suffusions (60\%), petechiae (26\%), or parenchimatous hematomas $(26 \%)$. In $12 \%$ of cases, two or more of these findings occurred combined.

INFECTIONS - Fifteen patients (1.5\%) had CNS infections. In most cases, the etiological agent was a bacteria or a virus, either in the HL or the NHL group (Table 3). All the infections occurred in patients on advanced stages of the lymphoma. The clinical pictures corresponded to meningoencephalitis or meningitis in 7 cases. One patient had a brain abscess caused by Staphyloccccus aureus. In the remaining patients, the clinical picture consisted of confugion and focal findings without meningeal irritation signs. Diagnosis was nade at autopsy in these cases.

\begin{tabular}{|c|c|c|c|}
\hline \multirow{2}{*}{ Agent } & \multicolumn{3}{|c|}{ No of cases } \\
\hline & NHL, & HL & Total \\
\hline Herpes zoster vírus & 3 & 3 & 6 \\
\hline Cryptococcus neoformans & 2 & - & 2 \\
\hline Pseudomonas aeruginosa & - & 2 & 2 \\
\hline Listeria monocytogenes & 1 & 1 & 2 \\
\hline Haemophilus influenzae & - & 1 & 1 \\
\hline Staphylococcus aureus & 1 & - & 1 \\
\hline Trypanosoma cruzi & - & 1 & 1 \\
\hline Total & 7 & 8 & 15 \\
\hline
\end{tabular}

Table 3 - Etiologies of brain and meningeal infections in patients with lymphoma. NHL, non-Hodgkin's lymphoma; HL, Hodgkin's lymphoma.

COMPLICATIONS FROM TREATMENT - Thirty-six autopsies were performed. Lesions that can be relater to treatment, i.e., circumscribed or diffuse demyelination areas, microcalcifications, coagulative necrosis or gliosis, were seen in 8 patients (Table 4). One patient, who had been treated with RT alone, had cerebral microcalcifications. In this case, lesions can be ascribed to RT. In the other cases, it was not possible to single out a definttive relationship between the pathological findings and treatment, since more than one of the therapeutic agents used could have caused demyelination.

Nineteen patients had two or more forms of craniocerebral involvement. The most frequent associations were: hemorrhage with lymphomatous infiltration (8 cases), and infiltration with infection (4 cases). 


\begin{tabular}{|c|c|c|c|c|}
\hline Case & IT Mtx & $\mathrm{RT}$ & $\mathrm{sch}$ & Pathological findings \\
\hline 1 & + & + & COPP/BACOPP & Diffuse demyelination \\
\hline 2 & 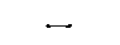 & + & - & Microcalcifications \\
\hline 3 & + & + & Cy-Pred & $\begin{array}{l}\text { Focal demyelination } \\
\text { Gliosis }\end{array}$ \\
\hline 4 & $t$ & + & Cy-Pcb-Pred & Focal demyelination \\
\hline 5 & + & + & Vnb-Leuk & $\begin{array}{l}\text { Focal demyelination } \\
\text { Coagulative necrosis }\end{array}$ \\
\hline 6 & +- & + & $\mathrm{Cy}-\mathrm{Vnc}-\mathrm{Pcb}$ & $\begin{array}{l}\text { Focal demyelination } \\
\text { Gliosis }\end{array}$ \\
\hline 7 & + & + & Cy-Pred & Focal demyelination \\
\hline 8 & + & + & BACOPP & $\begin{array}{l}\text { Focal demyelination } \\
\text { Coagulat1ve necrosis }\end{array}$ \\
\hline
\end{tabular}

Table 4 -Complications from treatment in patients with lymphoma. IT Mtx, intrathecal methotrexate; $R T$, radiation therapy; $S C h$, systemic chemothercpy; Cy, cyclophosphamide; Pred, prednisone; $P c b$, procarbazine; Vnb, vimblastine; Leuk, leukeran; Vnc, vincristine; $C O P P$, cyclophosphamide, vincristine, predisone, and procarbxzine; BACOPP, blocamycine, adryamicine, cyclophosphamide, prednisone, vincristine, and procarbazine.

\section{COMMENTS}

Different series reported varying incidences of brain and meningeal lymphomatous infiltration in patients with lymphoma. Figures varied between 2 and $29 \%$ in patients with NHL4,21,29,34,40,53,66. In the case of HL, there have been either few reports or series with a small number of patients $8,43,56,61$; Sapozinck and Kaplan reported an incidence of $0.5 \% 56$. In our series, $6.9 \%$ of the NHL and $2.8 \%$ of the HL patients had evidence of craniocerebral lymphomatous infiltration. In the HL group, this complication occurred at a 10-year younger age than in the NHL group, perhaps reflecting the earlier age of onset of HL. However, the duration of the hematological disease, at the time of the CNS infiltration, was twice as long in the HL group (52.9 vs 26.4 months, respecti$v \in l y)$. Neurological involvement was the first manifestation of the disease in $13 \%$ of cases of NHL. On the contrary, no case of HL had neurological involvement at the onset, in agreement with other series $33,56,60$. Generally, brain lymphomatous infiltration is seen on advanced stages of the lymphomas, and is associated with histological types like diffuse histiocytic lymphoma (DHL) and diffuse poorly differentiated lymphocytic lymphoma (DPDLL) 4,21,34,37. Brain infiltration is infrequent in patients with $\mathrm{HL}$ or NHL of nodular type $4,17,21,34,37,40$, although it may occur in the latter after transformation to a diffuse form $34,37,66$. Meningeal lymphomatous involvement has been reported in pathological studies of up to $76 \%$ of patients with Burkitt's lymphoma with early relapse of the disease after treatment (within 3 months) $27,36,67$. Sixty-five per cent of the patients with brain infiltration were on advanced stages of the disease, i.e., IV A or B. In patients with NHL, DPDLL accounted for $38 \%$ of the cases and, DHL for $36 \%$, in agreement with other authors $34,37,66$. In the group of patients with $\mathrm{HL}$, we found a greater incidence of histological types of mixed cellularity $(66.6 \%)$. There have been controversial results in this regard in the different published series 8,11,56. Between 9.5 and $73 \%$ of the lymphomatous meningeal infiltrations are asymptomatic and are diagnosed at autopsy 17,24,66. In our series, 32\% of meningeal infiltrations fell into this category.

Lymphomatous orbital involvement may occur isolated or combined with widespread disease. Lazzarino et al.35 found orbital infiltration in $2.4 \%$ of patients with NHL. All these cases represented immunologically monoclonal B-cell proliferations. Sixty-two per cent of these patients had systemic involvement expressed as cutaneous or suocutaneous nodules. There was a much lower incidence of systemic involvement in our series $(1 \%)$, perhaps reflecting a predominance of nodular or low grade malignant forms $(60 \%)$. Patients with DHL or DPDLL, and orbital infiltration were on stages III or IV of the disease. They had orbital erosion in 50\% of the cases, which represented a sign of poor prognosis, in agreement with other series 1,32,35 Bone marrow lymphomatous infiltration is seen in 60 to $100 \%$ of patients with brain 
infiltration 17,37,40. This association suggests dissemination from the bone marrow to the dura, subarachnoid space, and subsequent invasion to the Virchow-Robin space. The incidence of bone marrow infiltration in patients with early DHL is significantly lower than in patients with nodular forms (15 vs $40 \%$, respectively). However, meningeal involvement in the former is frequent 17. There is no clear explanation for this fact 4. We found bone marrow involvement in $70 \%$ of the cases of lymphoma with craniocerebral infiltration. In the case of $\mathrm{HL}$ with brain and meningeal infiltration, the bone marrow was involved in all cases. In the cases of brain and meningeal infiltration without bone marrow involvement, the initial lymphomatous infiltration occurred in the nasal cavum, orbit, or spinal nerve roots, from where the disease disseminated to the CNS.

Lymphoma cells could be demonstrated in $78 \%$ of the CSF studies of patients with craniocerebral infiltration. According to different series $2,21,42,66$, lymphoma cells can be seem in the CSF study in 70 to $88 \%$ of the patients with craniocerebral infiltration when these studies are performed with cytocentrifugation techniques. However, these figures can drop to $50 \%$, if only one $\operatorname{CSF}$ sample is drawn 42,66. Most authors recommend the study of at least three samples of CSF when looking for lymphoma cells. The study of surface markers, the identification of deoxynucleotidyltransferase, and the use of immunocytochemical techniques on CSF lymphocytes decrease the number of false positive results due to viral or mycotic infections 13,14,16,25,39. The CT scan of the head is not a very useful test to detect meningeal lymphomatous infiltrations. Even using larger doses of contrast, enhancement similar to that occurring in patients with infectious or carcinomatous meningitis is not frequently seen $3, \mathbf{2 2 , 4 8}$. On the contrary, brain focal parenchymatous infiltrations tend to appear as iso or hyperdense masses in contact with the cortical surface or the ependymum. This fact would suggest dissemination to the brain parenchyma from the dura and CSF 48. In patients with orbital infiltrations, enlargement of the optic nerve can be seen on the CT scan 3 . In our series CT scan findings were similar to those reported by others. In only one case of meningeal infiltration, was periependymal contrast enhancement observed on the CT scan. Conversely, the CT scan was very useful in revealing brain focal parenchymatous infiltrations.

Different conditions have been considered as risk factors predisposing to brain involvement in lymphomas. Specifically, the presence of a DPDLL, a diffuse indifferentiated histological type, prior treatment with $\mathrm{SCh}$, bone marrow involvement, age below 35 years, or extranodal involvement, havc been singled out as risk factors 34,40 . The combination of these factors permits the prediction of the risk of CNS infiltration for each patient through a multivariable regression model. With the above mentioned data, Litam et al. 40 proposed a table that would group patients as having low, medium, or high risk of infiltration of the CNS. In our series, $95 \%$ of the patients met the criteria for inclusion in the high risk group for craniocerebral infiltration.

The lack of a uniform protocol for the treatment of these patients, as well as the different clinical forms observed, did not allow us to draw valid conclusions on the efficacy of any single therapeutic approach. However, there are two important observations. In the first place, when using combined $\mathrm{SCh}$, RT, and ITMtx for the treatment of meningeal lymphomatous infiltrations, we observed a mean survival time of 4.3 months. In other series it is reported 52 a mean survival time of 8 months with the use of Ommaya reservoirs for the intrathecal administration of chemotherapeutic agents, along with RT in the same situation. Therefore, this would suggest the possible usefulness of the administration of chemotherapy with this technique. Secondly, consideration should be given to chemotherapeutic prophylactic treatment in patients at high risk for brain and meningeal lymphomatous infiltrations $29,40,49$, since $80 \%$ of these occur within 5 months following treatment. Thus, prophylaxis should start early in the course of treatment, e.g., in the first three months 40 .

In our series, there were two cases of PCL, both documented with pathological studies. Even though PCL used to represent only 0.3 to $1.5 \%$ of all brain tumors 26,59 , there has been an increase of its incidence because of the higher current number of patients with immunodeficiency $20,26,28,38,46$. These conditions increase up to 350 times the chance of developing PCL20,26,46. Our two cases did not have immunodeficiency. Other authors have related PCL in patients without imunodeficiency to Epstein-Barr virus infection 18,23 . Unfortunately, we did not look for that contigency in our two patients. Hemorrhagic phenomena were observed in $2 \%$ of patients. Except for two cases, there was a clear relationship between the presence of hemorrhage and abnormalities in the platelet function or count. This suggests that brain bleeding in 
patients with lymphoma is related to bone marrow involvement from lymphomatous infiltration or from chemotherapy toxicity. As opposed to intracranial hematomas, brain suffusions and petechiae are more frequently an autopsy finding, as previously suggested 9. Patients with lymphoma are well-known for their predisposition to infections. Opportunistic agents, the association of different infectious agents compromising the same host, or the appearance of several infectious foci, are a frequent occurrence in these patients 26,54. According to Hooper et al.26, 2.7\% of patients with HL and $0.6 \%$ of those with NHL develop some kind of CNS infectious complication in the course of their disease. In our series, the incidence of such complication was 1.9 and $1.2 \%$ in each group, respectively. Because of their poor symptomatology, early diagnosis of the CNS infection is frequently difficult in these patients 54 . In 7 cases $(46 \%)$, diagnosis of CNS infection was made at autopsy, in agreement with other series 7. Common bacteriae, as well as opportunistic agents, are capable of causing CNS infections in immunocompromised patients at varying frequencies 6,7,26. In our series, we observed a predominance of bacterial and viral agents, even though we also found Trypanosoma cruzi, a parasite, causing one case of meningoencephalitis. This last entity was initially described in 191162, and was subsequently seen in patients with immunodeficiency from different etiologies 30,45 .

Previous work has reported neurotoxicity from IT Mtx, RT, and less frequently, from $\mathrm{SCh} 10,15,19,31,44,47,50,55,57,58,63-65$. Lesions are much more frequent in the white matter of the brain and consist of foci of oligodendrocyte loss with severe reactive astrocyte proliferation, coagulation necrosis of the vascular endothelium, fibrinoid degeneration, and vascular thrombosis $57,58,63$, Occasionally, there are associated calcifications $15,19,47,55$. The clinical picture corresponds to a progressive encephalopathy with confusion, seizures, spasticity, ataxia, coma, and death $10,31,44$. In $22 \%$ of the autopsies, we found elements suggesting lesions secondary to treatment, i.e., focal or diffuse demyelination, microcalcifications, coagulative necrosis, or gliosis. In only one case, could the use of RT as the only treatment, be held responsible for the observed demyelinating lesions. In the remaining cases, the lesions could have been caused by the combination of different therapeutic agents, while being difficult to single out the predominance of anyone of them in the origin of the process.

The current longer life expectancy in patients with lymphoma determined an increase in the appearance of the different types of craniocerebral involvement, most of which carry a severe prognosis. Awareness can lead to an early diagnosis and prompt treatment, which may provide relief and a longer survival time. Therefore, patients at high risck for lymphomatous infiltration should be considered for early prophylatic treatment. However, this point awaits further definition.

\section{RFHERENCES}

1. Bennett CL, Putterman A, Bitran JD - Staging and therapy of orbital lymphomas. Cancer $57: 1204,1986$.

2. Billingham ME, Rawlinson DG, Berry PF, Kempson RL - The cytodiagnosis of malignant lymphomas and Hodgkin's disease in cerebrospinal, pleural and ascitic flulds. Acta Cytol 19:547, 1975.

3. Brandt-Zawadski M, Enzmann DR - Computed tomographic brain scanning in patients with lymphoma. Radiology 129:67, 1978.

4. Bunn PA Jr, Schein FS, Banks PM, DeVita VT Jr - Central nervous system complications in patients with diffuse histiocytic and undifferentiated lymphoma: leukemia revisited. Blood $47: 3,1976$.

5. Carbone PP, Kaplan HS, Musshoff $K$, Smiters DW, Tubiana $M-$ Report of the Committee on Hodgkin's Disease Staging Classification. Cancer Res 31:1860, 191.

6. Chernik NL, Armstrong D, Posner JB -- Central nervous system infections in patients with cancer. Medicine 52:563, 1973.

7. Chernik NL, Armstrong $D$, Posner JB - Central nervous system infections in patients with cancer. Cancer 40:263, 1977.

8. Cuttner J, Mever R, Huang YP - Intracerebral involvement in Hudgkin's disease: a report of six cases and review of the literature. Cancer 43:1497, 1979.

9. Davies Jones GAB, Preston FE, Timperley WR - Neurological Complications in Clinical Hematology. Blackwell, Oxford, 1981, pg 98.

10. DeVivo DC, Malas D, Nelson JJ - Leukoencephalopathy in childhood leukemia. Neurology $27: 609,1977$.

11. Dillman RO, Mueh J, Greco $\mathrm{CM}$, Green MR - Leptomeningeal Hodgkin's disease. Ann Inter Med 92:714, 1980. 
12. Enzmann It, Krikorian J, Yorke-C, Hayward R - Computed tomography in leptomeningeal spread of tumor. J Comput Assist Tomogr 2:448, 1978.

13. Erenerudh J, Olsson T, Berlin G, Gustafsson B, Karisson H - Cell surface markers for diagnosis of central nervous system involvement in lymphoproliferative disease. Ann Neurol 20:610, 1986.

14. Eurin-Waters C, Klein M, Deck J, Lang AE - Diagnostic importance of immunological markers in lymphoma involving the central nervous system. Ann Neurol 16:668, 1984.

15. Flament-Durand $J$, Ketelbant-Balase $P$, Maurus $R$, Regnier $R$, Spehl $M$ - Intracerebral calcifications appearing during the course of acute lymphocytic leukemia treated with methotrexate and X-rays. Cancer 35:319, 1975.

16. Goodson J.D, Strauss GM - Diagnosis of lymphomatous leptomeningitis by cerebrospinal fluid lymphocyte cell surface markers. Am J Med 66:1057, 1979.

17. Griffin JW, Thompson RW, Mitchinson MJ, Kiewiet JC, Welland FH - Lymphomatous leptomeningtis. Am J Med 51:200, 1971.

18. Hanto DW, Frizzera G, Purtilo DT - Clinical spectrum of lymphoproliferative disorders in renal transplant recipients and evidence for the role of Epstefn-Barr virus. Cancer Res 41:4253, 1981 .

19. Harwood-Nash MB, Reilly BJ - Calcification of the basal ganglia following radiation therapy. Am I Radiol 108:392, 1970.

20. Helle TL, Britt RH, Colby TV - Primary lymphoma of the central nervous system: clinicopathological study and experience at Stanford. J Neurosurg 60:94, 1984.

21. Herman TS, Hammond $\mathrm{N}$, Jones SE, Butler JJ, Byrne GE, MaKelvey $\mathbf{E}$-. Involvement of the central nervous system by non-Hodgkin's lymphoma. Cancer 43:390, 1979.

22. Hochberg FH, Miller G, Schooley RT - Central nervous system lymphoma related to Epstein-Barr virus. N Engl J Med 309:745, 1983.

23. Hochberg FH, Miller DC - Primary central nervous system lymphoma. J Neurosurg $68: 835,1988$.

24. Höch D, Herold M, Kästner R, Anger G, Schreider D - Die Meningosis neoplastica bei unreifzelligen Leukosen und malignen Lymphomen. Folia Haematol 112:515, 1985.

25. Hooijkaas $\mathbf{H}_{\text {, }}$ van Dongen $\mathbf{J J}$, Hahlen $\mathbf{K}$, van Zanen GE - Inımunological characterisation of cells in cerebrospinal fluid from patients with lymphoid malignancies. Lancet 1:518, 1984.

26. Hooper DC, Pruitt AA, Rubin RH - Central nervous system infection in the chronically immunosuppressed. Medicine 61:166, 1982.

27. Janota $I-$ Involvement of the nervous system in malignant lymploma in Nigerla. Br $\mathrm{J}$ Cancer 20:47, 1966.

28. Jiddane M, Nicoli F, Diaz $\mathbf{P}$ - Intracranial malignant lymphoma: report of 30 cases and review of the literature. $J$ Neurosurg 65:592, 1986.

29. Johnson GJ, Oken MM, Anderson JR, O'Conell MJ, Glick JH - Central nervous system relapse in unfavourable histology non-Hodgkin's lymphoma: is prophylaxis indicated? Lancet 2:685, 1984.

30. Jost L, Turin M, Etchegoyen F', Leiguarda $R$, Torcuato A, Iotti $\mathbf{R}-$ Meningoencefalitis chagásica en paciente con tratamiento inmunosupresor por transplante renal. Rev Neurol Arg 3:425, 1977.

31. Kay HFM, Knapton PJ, O'Sullivan JP - Encephalopathy in acute leukemia associated with methotrexate therapy. Arch Dis Child $47: 344,1972$.

32. Knowles DM II, Jakobiec FA - Orbital lymphoid neoplasms: a clinicopathologic study of 60 patients. Cancer 46:576, 1980.

33. Lascalles R, Burston J - Hodgkin's disease presenting with symptoms of cranial nerve involvement. Arch Neurol $7: 359,1962$.

34. Law IP, Dick FR, Blom J, Berquein PR - Involvement of central nervous system in non-Hodgkin's lymphoma. Cancer 36:225, 1975.

35. Lazzarino $M$, Morra $\mathbf{E}$, Rosso $\mathbf{R}-$ Clinicopathologic and inmunologic characteristics of non-Hodgkin's lymphoma presenting in the orbit: a report of eight cases. Cancer 55:1907, 1985.

36. Levine PH, Kamaraiu LS, Lieberman PH - The American Eurkitt's lymphoma registry: eight years' experience. Cancer 49:1016, 1982.

37. Levitt LJ, Dawson DM, Rosenthal DS, Moloney WC - CNS involvement in non-Hodgkin's lymphoma. Cancer $45: 545,1980$.

38. Levy RM, Bredesen DE, Rosemblum ML - Neurological manifestations of the acquired immunodeficiency syndrome (AIDS): experience at UCSF and review of the literature. J Neurosurg 62:475, 1985.

39. Li C, Witzig TE, Phyliky RL, Ziesmer SC, Yam LT - Diagnosis of B-cell non-Hodgkin's lymphoma of the central nervous system by immunocytochemical analysis of cerebrospinal fluid lymphocytes. Cancer 57:737, 1986. 
40. Litan JP, Cabanillas F, Smith TL, Bodey GP, Freireich EJ - Central nervous system relapse in malignant lymphomas: risk factors and implications for prophylaxis. Blood $54: 1249,1979$.

41. Lukes RJ, Butler JJ - The pathology and nomenclature of Hodgkin's disease. Cancer Res 26:1063, 1966.

42. Mackintosh FR, Colby TV, Podulsky WJ - Central nervous system involvement in non-Hodgkin's lymphoma: an analysis of 105 cases. Cancer 45:586, 1982.

43. Marshall G, Roesman V, van den Noort S -- Invasive Hodgkin's disease of brain: report of two new cases and review of American and European literature with clinical pathologic correlations. Cancer 22:621, 1968 .

44. McIntosh S, Klatskin EM, O'Brien RT - Chronic neurologic disturbance in childhood leukemia. Cancer $37: 853,1976$.

45. Monteverde DA, Taratuto AL, Lucatelli $\mathrm{N}-$ Meningoencefalitis chagásica aguda en pacientes inmunosuprimidos. Rev Neurol Arg 2:260, 1976.

46. Moover R, Fraumeni JF Jr - Risk of cancer in renal transplant recipients. Lancet 2:55, 1973.

47. Mueller $S$, Bell $W$, Seibert $J$ - Cerebral calcifications associated to intrathecal methotrexate therapy in acute lymphocytic leukemia. $J$ Pediatr 88:650, 1976.

48. Pagani JJ, LJbshitz HI, Wallace S, Hayman LA - Central nervous system leukemia and lymphoma: computed tomographic ntanifestations. Am J Radiol 137:1195, 1981.

49. Perez-Soler R, Smith TL, Cabanillas F - Central nervous system prophylaxis with combined intravenous and intrathecal methotrexate in diffuse lymphoma of aggresive histologic type. Cancer $57: 971,1986$.

50. Peyland-Ramu N, Poplack DG, Pilzo DA, Adarnato BT, DiChiro G - Abnormal CT scans of the brain in asymutomatic children with acute leukemia after prophylactic treatment of the central nervous system with radiation and intrathecal chemotherapy. N Engl J Med 298:815, 1978.

51. Rappaport H - Tumors of hematopoietic system. In Atlas of Tumor Pathology. Armed Forces Institute of Pathology, Washington DC, 1966, pg 91.

52. Raz 1, Siegal $T$, Siegal T, Polliack A - CNS involvement by non-FIodgkin's lymphoma: response to a standard therapeutic protocol. Arch Neurol 41:1167, 1984.

53. Rosemberg SA, Diamond HD, Jaslowitz B, Craver LF - Lymphosarcoma: a review of 1269 cases. Medicine 40:31, 1961.

54. Rubin RH, Hooper DC - Central nervous system infection in the compromised host. In Molavi A, LeFrock JL (eds): Med Clin North Am. Saunders, Philadelphia, 1985, pg 281.

55. Rubinstein LJ - Radiation changes in intracranial neoplasms and the adjacent brain. In Tumours of the CNS. Atlas of Tumor Pathology. Armed Forces Institute of Pathology, Washington DC, 1972, pg 349.

56. Sapozink MD, Kaplan HJ - Intracranial Hodgkin's disease: a report of 12 cases and review of the literature. Cancer 52:1301, 1983.

57. Shapiro WR, Chernik NL - Necrotizing encephalopathy following intraventricular instillation of methotrexate. Arch Neurol 28:96, 1973.

58. Smith B -. Brain damage after intrathecal methotrexate. I Neurol Neurosurg Psychiat $38: 810,1975$.

59. Spillane JA, Kendall BE, Moseley IF - Cerebral lymphoma: clinical radiological correlation. I Neurol Neurosurg Psychiat 15:199, 1982.

60. Steinherz PG, Walker R, Kroll G - Lymphomatous leptomeningitis as a presenting symptom of Hodgkin's disease. Ann Intern Med 99:342, 1983.

61. Thompson RW, DeNardo GL - Therapeutic response of intracranial Hodgkin's disease documented by brain scanning. Cancer 24:981, 1969.

62. Vianna $G$ - Contribuição para o estußlo da anatomia patológica de moléstia de Chagas. Mem Inst Osw Cruz 3:276, 1911.

63. Weiss HD, Walker MD, Wiernik PH - Neurotoxicity of commonly used antineoplastic agents: first of two parts. N Engl J Med 291:75, 1974.

64. Weiss HD, Walker MD, Wiernik PH - Neurotoxicity of commonly used antineoplastic agents: second of two parts. N Engl J Med 291:127, 1974.

65. Winkelman MD, Hines JD - Cerebellar degeneration caused by high dose cytosine arabinoside: a clinicopathological study. Ann Neurol 14:520, 1983.

66. Young RC, Howser DM, Anderson $\mathbf{T}-$ Central nervous system complications of non-Hodgkin's lymphoma. Am J Med 66:435, 1979.

67. Ziegler JL, Bluming AZ, Morrow RH, Fass L, Carbone PP - Central nervous system involvement in Burkitt's lymphoma. Blood $36: 718,1970$. 